\title{
Effects of dietary fat and L-methionine on the hepatic metabolism of very low density lipoproteins in the preruminant calf, Bos spp
}

\author{
S Auboiron 1, D Durand 1, JC Robert ${ }^{2}$, \\ MJ Chapman ${ }^{3}$, D Bauchart ${ }^{*}$ *
}

\author{
1 INRA-Theix, unité de recherches Métabolismes énergétique et lipidique, \\ laboratoire Croissance et métabolismes des herbivores, 63122 Saint-Genès-Champanelle; \\ 2 Rhône Poulenc Nutrition Animale, 03600 Commentry; \\ 3 Hôpital de la Pitié, unité de recherches sur les lipoprotéines et l'athérogenèse, \\ INSERM U321, 75651 Paris cedex, France
}

(Received 2 August 1994; accepted 11 January 1995)

\begin{abstract}
Summary - The effects of triglycerides (TG) from tallow (1.21 and $2.13 \mathrm{~g} \mathrm{TG} / \mathrm{kg}$ of body weight (BW) per meal, diets $R$ and $B$ respectively) and from tallow plus cream $(2.50 \mathrm{~g} \mathrm{TG} / \mathrm{kg}$ of BW per meal, diet L) with or without L-methionine (2.6 $\mathrm{g} / \mathrm{kg}$ dry matter) on hepatic apparent secretion of very low density lipoproteins (VLDL) were investigated in 3 groups of 4 preruminant calves fitted with chronic catheters and with electromagnetic blood-flow probes implanted in their hepatic vessels. Increasing TG concentrations stimulated the apparent VLDL secretion by the liver $(1.02,-0.36$ and $-1.51 \mathrm{mg}$ VLDL mass/min per $\mathrm{kg}$ of $\mathrm{BW}$ in diets $\mathrm{L}, \mathrm{B}$ and $\mathrm{R}$, respectively). $\mathrm{L}-\mathrm{Methionine}$ increased this secretion when associated with the lipid-restricted (diet R; 0.25 and $-1.51 \mathrm{mg} \mathrm{VLDL} / \mathrm{min}$ per $\mathrm{kg}$ of BW) and basal (diet B; 0.35 and $-0.36 \mathrm{mg}$ VLDL/min per $\mathrm{kg}$ of BW) diets (non-significant). However, the VLDL apparent secretion decreased with the lipid-enriched diet (diet $L$ ), which suggests an insufficient dose of Lmethionine compared with the level of TG intake, and a possible competition between liver and intestine for utilization of L-methionine for the synthesis of TG-rich lipoproteins.
\end{abstract}

L-methionine / dietary triglycerides / VLDL / hepatic metabolism / preruminant calf

Résumé - Effets des matières grasses et de la L-méthionine sur le métabolisme hépatique des lipoprotéines de très basse densité chez le veau préruminant, Bos spp. Les effets des triglycérides (TG) du suif $(1,21$ et $2,13 \mathrm{~g}$ de $T G / \mathrm{kg}$ de poids vif et par repas, lots $R$ et $B$ ) et du suif addi-

* Correspondence and reprints.

Abbreviations: Apo B, apolipoprotein B; BW, body weight; CE, cholesteryl esters; EDTA, ethylenediaminetetraacetic acid; FC, free cholesterol; HV, hepatic vein; MA, mesenteric artery; NEFA, non-esterified fatty acids; PL, phospholipids; PV, portal vein; TC, total cholesterol; TG, triglycerides; VLDL, very low density lipoproteins. 
tionné de crème $(2,50 \mathrm{gTG} / \mathrm{kg}$ PV et par repas, lot $L)$ associés ou non à de la $\mathrm{L}$-méthionine $(2,6 \mathrm{~g} / \mathrm{kg}$ MS) sur la sécrétion hépatique apparente de lipoprotéines de très basse densité (VLDL), ont été étudiés sur 12 veaux préruminants équipés de cathéters et de sondes électromagnétiques implantés dans les vaisseaux hépatiques. La sécrétion apparente de VLDL par le foie s'accroît avec le taux de lipides du lait $(+1,02$ vs $-0,36$ vs $-1,51 \mathrm{mg} V L D L \mathrm{~min} / \mathrm{kg} P V$ avec les lots $L, B$ et $R$ ). De même, la $L$ méthionine stimule cette sécrétion apparente mais non significativement avec les lots $R(+0,25$ vs $-1,51$ $\mathrm{mg} V L D L / \mathrm{min} / \mathrm{kg} P V)$ et $B(+0,35 \mathrm{vs}-0,36 \mathrm{mg} / \mathrm{min} / \mathrm{kg} P V)$, mais la réduit avec le lot $L$ suggérant que l'apport de L-méthionine est insuffisant à haut niveau d'apport en lipides. De plus, une possible compétition entre le foie et lintestin pourrait limiter l'efficacité de la L-méthionine en situation de fort recyclage de lipides par le foie.

\section{L-méthionine / triglycéride alimentaire / VLDL / métabolisme hépatique / veau préruminant}

\section{INTRODUCTION}

During early lactation, high-producing dairy cows are in a state of negative energy balance, which is associated with a large increase in plasma non-esterified fatty acids (NEFA) mobilized from the body fat stores (Reid et al, 1983). In these animals, NEFA are mainly taken up by the liver and incorporated into stored triglycerides in the hepatocytes (Kleppe et al, 1988; Pullen et al, 1988; Bauchart, 1993). These animals are thus susceptible to having a fatty liver because bovine hepatocytes have a limited capacity to export triglyceride-rich lipoproteins such as very low density lipoproteins (VLDL) (Reid et al, 1979a; Herdt et al, 1988; Kleppe et al, 1988; Pullen et al, 1988; Bauchart et al, 1989). If lipid infiltration of the liver becomes severe, gluconeogenesis (a vital function of the liver) may be compromised (Armentano et al, 1991), predisposing the cows to ketosis (Zammit, 1990; Grummer, 1993). Under such conditions, high-producing dairy cows may exhibit increased susceptibility to infectious diseases and may manifest reproductive difficulties (Reid et al, 1979b, 1983).

Hepatic export of triglycerides (TG) via the secretion of VLDL may be influenced by a spectrum of stimuli that include genetic and dietary factors and a variety of hormones. Although chronic feeding of fatty acids or cholesterol does not stimulate VLDL apolipoprotein (apo) B synthesis in the liver of non-human primates (Sorci-Thomas et al, 1989), increasing the levels of plasma NEFA in the dairy cow (Pullen et al, 1989) and those of dietary cholesterol in the calf (Leplaix et al, 1992) led to a slight increase of VLDL secretion by the liver. Similarly, administration of estrogens, such as $17 \beta$ estradiol to preruminant calves (Auboiron et al, 1992) and dairy cows during early lactation (Grummer et al, 1989), stimulated hepatic secretion of VLDL. However, 17及estradiol appeared to have distinct effects on the hepatic metabolism in the calves depending on the dose or the mode of administration (Auboiron et al, 1992).

Sulfur-containing amino acids, such as L-methionine or methionine derivates (methionine hydroxy analogs, MHA), have been extensively studied in bovines because they improve milk production and increase the milk fat and protein contents in lactating cows (Chow et al, 1990) and goats (Emmanuel and Kennelly, 1984). As suggested by Moore and Christie (1981), the increase in milk fat production induced by L-methionine might result from the enhanced synthesis of VLDL constituents (apolipoproteins, lecithin) by the liver, which then increased the availability of the lipids required for the synthesis of milk fat by the mammary gland. The hepatocytes of methionine-deficient rats secreted VLDL at only $30 \%$ of the normal rate, and the addition of $L$-methionine to the deficient hepatocytes 
restored the secretion of VLDL to normal levels (Yao and Vance, 1988). However, feeding MHAs to dairy cows during early lactation did not increase the hepatic secretion of triglycerides (Pullen et al, 1989). This lack of effect might be explained by premature bacterial degradation of MHAs during the passage of the digestive contents in the rumen (Patterson and Kung, 1988).

The objective of the present study was to determine the specific effects of adding Lmethionine to the milk diet of preruminant calves (a functional monogastric animal) on the in vivo apparent secretion of VLDL by the liver. The animals were divided into 3 groups and were adapted to a standard TG diet, a diet with restricted TG, or a TG-rich diet. The TG-rich diet is associated with potential impairment of hepatic metabolism. The effects of dietary TG and L-methionine on the physicochemical properties and metabolism of the main lipoprotein classes of peripheral blood in the preruminant calf have been presented elsewhere (Auboiron et al, 1994).

\section{MATERIALS AND METHODS}

\section{Animals and diets}

The experiments were conducted using 3 groups of 4 preruminant, crossbred Friesian-Holstein male calves. The animals in group 1 were $5( \pm 2)$ weeks old ( $57 \pm 19 \mathrm{~kg}$ of $\mathrm{BW}$ ). In group 2, animals were $3( \pm 0)$ weeks old $(58 \pm 6 \mathrm{~kg} \mathrm{BW})$ and those in group 3 were $4( \pm 1)$ weeks old $(68 \pm 5 \mathrm{~kg}$ BW). The animals were housed on a litter of wood shavings in an air-conditioned shed (average temperature: $20^{\circ} \mathrm{C}$; hygrometric level: $80 \%$ ).

The calves of the 3 groups were equipped with chronic catheters which were fitted in the hepatic afferent (portal vein and mesenteric artery) and efferent (hepatic vein) vessels, as described by Bauchart et al (1989). The blood-flow rates were determined by electromagnetic flowmetry (Gould Inc, Statham Instruments Div, Oxnard, CA, USA) permitting determination of net lipopro- tein balance across the liver. Two probes were placed around the portal vein (15 $\mathrm{mm}$ id) and the hepatic artery (left branch; $3 \mathrm{~mm}$ id), as outlined by Durand et al (1988).

The basal diet was a milk replacer and was bucket-fed in 2 equal meals per day $(08.00$ and $16.00 \mathrm{~h}$ ). It contained $16 \%$ dry matter (DM) which was composed of $68 \%$ spray-dried skim milk powder (ie $22.8 \%$ weight protein and $0.59 \%$ weight methionine), $23.0 \%$ tallow, $6.8 \%$ corn starch, and $2.2 \%$ vitamin and mineral mixture (Univor 22 , Sodiavit, Montferrand, France). The total lipid and fatty acid content of the milk powder amounted to 24.1 and $22.0 \%$ of the DM, respectively.

The calves in group 1 were adapted over a 4 d period to a restrictive diet (diet $R$ ) which contained $30 \%$ of the DM of the basal conventional diet (Toullec, 1978) $(1.21 \pm 0.05 \mathrm{~g}$ of TG/ $/ \mathrm{kg}$ of BW per meal) to which $2.3 \mathrm{~g} / \mathrm{kg}$ of cystine (Sigma Chemical, Saint Louis, MO, USA) was added to the milk powder in order to compensate for the protein deficit. The calves in group 2 were similarly adapted to the basal diet (diet $B ; 2.13 \pm 0.13 \mathrm{~g}$ of $T G / \mathrm{kg}$ of BW per meal), and those in group 3 were adapted to the basal diet to which $125 \mathrm{~g}$ cream $/ \mathrm{kg}$ of diet DM (diet $\mathrm{L}, 2.50 \pm 0.22 \mathrm{~g}$ of $T G / k g$ of BW per meal) was added for $6 \mathrm{~d}$. Finally, all the calves received the same respective diets to which L-methionine was added $(2.6 \mathrm{~g} / \mathrm{kg}$ of DM; Rhône Poulenc Animal Nutrition, Commentry, France) for 4 consecutive days (diets RM, $B M$ and $L M$ ).

\section{Blood samples}

Blood $(20 \mathrm{ml})$ was collected simultaneously from each of the 3 catheterized vessels (hepatic vein, portal vein and mesenteric artery) into $\mathrm{Na}_{2}$-EDTA tubes (final concentration $1 \mathrm{mM}$ ) at peak lipid absorption ( $7 \mathrm{~h}$ after the morning meal). Plasma then was separated by centrifugation at $4500 \mathrm{rpm}$ for $10 \mathrm{~min}$ at $4^{\circ} \mathrm{C}$ and stored at $4^{\circ} \mathrm{C}$ until lipoprotein fractionation was initiated, typically within 24 $h$ of its isolation.

\section{Lipoprotein isolation}

The different ultracentrifugation steps used for lipoprotein fractionation were performed in a Kontron model Centrikon T-2060 ultracentrifuge using a TST 41-14 swinging bucket rotor. Chylomicrons 
(Sf flotation coefficient in Svedberg units $>400$ ) were first removed from the plasma by ultracentrifugation flotation for $45 \mathrm{~min}$ at $20000 \mathrm{rpm}$ $(52000 \mathrm{~g})$ and $15^{\circ} \mathrm{C}$ according to Zilversmit (1969). The VLDL (density $<1.006 \mathrm{~g} / \mathrm{ml}$ ) were then isolated from the chylomicron-free plasma by ultracentrifugation flotation for $16 \mathrm{~h}$ at $40000 \mathrm{rpm}$ (220 000 g) and $15^{\circ} \mathrm{C}$ (Bauchart et al, 1989).

\section{Chemical analysis}

The techniques used for measurements of the concentrations of the different classes of lipids, in both total plasma and lipoprotein fractions, have been described previously (Bauchart et al, 1989). Total cholesterol (TC) and free cholesterol (FC) were measured enzymatically using the reagent kit supplied by Merck (CHOD-iodide, Merckotest N14350, Darmstadt, Germany). Cholesteryl ester (CE) content was calculated using the relationship: $C E=(T C-F C) \times 1.68$. Triglyceride content was estimated by the enzymatic method using Biomérieux reagent kit (PAP 100, No 6126.6, Biomérieux, Charbonnières-les-Bains, France) which determines total free glycerol content. Phospholipids (PL) were determined enzymatically involving use of Biomérieux kit (PAP 150, No 6149.1). The colorimetric method of Bicinchininic Acid Protein Assay Reagent (Pierce, Rockford, IL, USA) was used for the assay of protein concentrations.

\section{Immunological analysis}

The apo B content of the VLDL particles was determined by radial immunodiffusion according to the technique of Mancini et al (1965) adapted to the bovine apolipoprotein by Auboiron et al (1990) and using an antiserum to calf apo $B$ (purified from bovine $L D L$ ) raised in rabbits (Auboiron et al, 1990).

\section{Calculation of hepatic balance}

The hepatic balance was determined from bloodflow measurement in the portal vein and mesenteric artery, and from the plasma concentrations of VLDL isolated by flotation ultracentrifugation from plasma drawn from the mesenteric artery, portal vein (afferent vessels) and hepatic vein (efferent vessel) (Bauchart et al, 1989). Plasma flow rates were corrected for packed-cell volume.

The hepatic afferent VLDL flow (mg/min per $\mathrm{kg}$ of $\mathrm{BW})=\left(C_{\mathrm{PV}} \times F_{\mathrm{PV}}\right)+\left(C_{\mathrm{MA}} \times F_{\mathrm{HA}}\right)$, where $F_{\mathrm{PV}}$ and $F_{\mathrm{HA}}$ are the portal and hepatic arterial plasma flow rates $(\mathrm{ml} / \mathrm{min}$ per $\mathrm{kg}$ of $B W$ ) respectively, and $C_{\mathrm{PV}}$ and $C_{\mathrm{MA}}$ are the portal and mesenteric arterial VLDL plasma concentrations ( $\mathrm{mg} / \mathrm{dl}$ ) respectively. Hepatic efferent plasma flow was considered as being equal to hepatic afferent plasma flow which was calculated as: hepatic efferent VLDL flow $=C_{\mathrm{HV}}\left(F_{\mathrm{PV}}+F_{\mathrm{HA}}\right)$, where $C_{\mathrm{HV}}$ is the hepatic venous plasma VLDL concentration $(\mathrm{mg} / \mathrm{dll})$. We assumed that the hepatic balance corresponded to the amount of VLDL removed (negative balance) or produced (positive balance) by the liver. Thus, VLDL hepatic balances could be calculated from the following equations (Bauchart et al, 1989): VLDL hepatic balance $=C_{\mathrm{HV}}\left(F_{\mathrm{PV}}+F_{\mathrm{HA}}\right)-\left(C_{\mathrm{PV}} \times F_{\mathrm{PV}}\right)+\left(C_{\mathrm{MA}} \times F_{\mathrm{HA}}\right)$.

\section{Statistical analysis}

The nonparametric $U$-test of Mann and Whitney (1947) was used to estimate the statistical significance of the differences observed between the different parameters studied (plasma concentration, composition and hepatic balance of the VLDL) from the 3 groups of calves. The level of significance of the correlation coefficients $(r)$ between the ingested amount of triglycerides $(x)$ and VLDL plasma level $(y)$ VLDL hepatic balance $=C_{\mathrm{HV}}\left(F_{\mathrm{PV}}+F_{\mathrm{HA}}\right)-\left(C_{\mathrm{PV}} \times F_{\mathrm{PV}}\right)+\left(\left(C_{\mathrm{MA}} \mathrm{X}\right.\right.$ $\left.F_{H A}\right)(y)$ for each set of data were determined from the table published by Snedecor and Cochran (1967).

\section{RESULTS}

The concentrations of the major plasma lipids in the mesenteric artery (peripheral blood) were determined in the preruminant calves fed the lipid-restricted diet (diet $R$, $1.21 \mathrm{~g}$ of TG $/ \mathrm{kg}$ of BW per meal), the basal diet (diet B, $2.13 \mathrm{~g}$ of $\mathrm{TG} / \mathrm{kg}$ of BW per meal) and the lipid-supplemented diet (diet $L$, $2.50 \mathrm{~g}$ of TG/ $\mathrm{kg}$ of BW per meal) or these diets supplemented with L-methionine (diets 
RM, BM and LM, $2.6 \mathrm{~g} / \mathrm{kg}$ of DM intake) and are shown in table I. For all the diets used in this experiment, the plasma lipids were dominated by $C E$ ( $35.7-41.9 \%$ of total lipids) and by phospholipids $(38.0-42.2 \%)$. Triglycerides $(9.0-14.4 \%), \mathrm{FC}(1.9-3.4 \%)$ and NEFA $(4.4-10.9 \%)$ were a minor plasma lipid component in these diets. Mean plasma concentrations of lipids were generally lower for diets $R$ and RM than for the other diets, with the exception of NEFA in the 3 control diets (diets $R, B$ and $L$ ) for which plasma levels were correlated inversely with the lipid intake (table I).

Addition of L-methionine to the control diet did not in general modify the plasma concentrations of the lipids irrespective of the quantity of fat ingested. It did lead, however, to a net decrease in plasma NEFA levels; the maximal effect was observed for diets $\mathrm{RM}(-56 \%)$ and $\mathrm{BM}(-55 \% ; P<0.10)$.

As shown in figure 1, the lipid distribution of plasma VLDL in the 3 hepatic vessels (mesenteric artery, portal and hepatic veins) of the calves fed control and methionine-supplemented diets was modified by the level of fat intake, but no marked difference was noted between the vessels. As compared to the basal diets (diets $B$ and $B M)$, and more particularly the lipid-supplemented diets (diets $L$ and $L M$ ), the VLDL particles in calves fed lipid-restricted diets (diets $R$ and $R M$ ) exhibited mean $C E$ and FC contents which were 1.9-12.9 and 1.5-2.7 times higher, respectively, and which occurred to the detriment of the TG content $(-20.7$ to $-31.0 \%$ ) (table II). Similar decreases in apo B content of total VLDL particles $(-57.7$ to $-53.4 \%)$ were observed on lipid-supplemented diets as compared to lipid-restricted diets (table III).

Plasma concentrations of VLDL increased with fat intake in the 3 hepatic vessels (table IV). The regression coefficient for the correlation between individual values of plasma VLDL concentrations in the mesenteric artery $(y, \mathrm{mg} / \mathrm{dl})$ and fat intake $(x, \mathrm{~g} / \mathrm{kg}$ of BW per meal) on the con-

Table I. Total concentration $(\mathrm{mg} / \mathrm{dl})$ of the major lipids in plasma from a mesenteric artery of preruminant calves fed lipid-restricted diet (diet R), basal diet (diet B) and lipid-enriched diet (diet L) or these diets supplemented with L-methionine ( $2.6 \mathrm{~g} / \mathrm{kg}$ dry matter; diets RM, BM and LM).

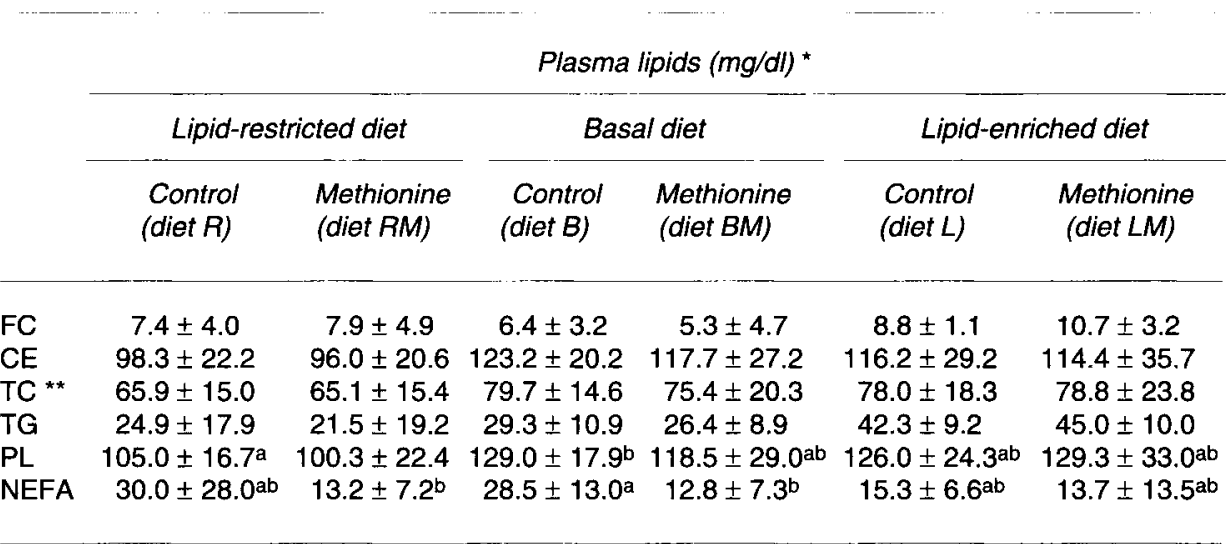

\footnotetext{
* Values are the mean \pm SEM of duplicate analyses on plasma from 4 calves in each group. Plasma from these animals were used for TG-rich lipoprotein isolation by flotation ultracentrifugation. ${ }^{*}$ Values for TC represent the serum-free and esterified cholesterol. ${ }^{a-b}$ Mean values with different superscript letters are significantly different $(P<0.10)$.
} 
trol and methionine-supplemented diets are shown in figure 2. The relationship between these variables was linear and highly significant for the 2 groups of diets (control diets: $y=7.70 x-5.54 ; r=0.76$,
$P<0.01$; methionine-supplemented diets: $y=14.73 x-15.83 ; r=0.94, P<0.001)$. Calculation of the slope ratio (concentrations of VLDL in methionine-supplemented diets versus control diets) indicated that

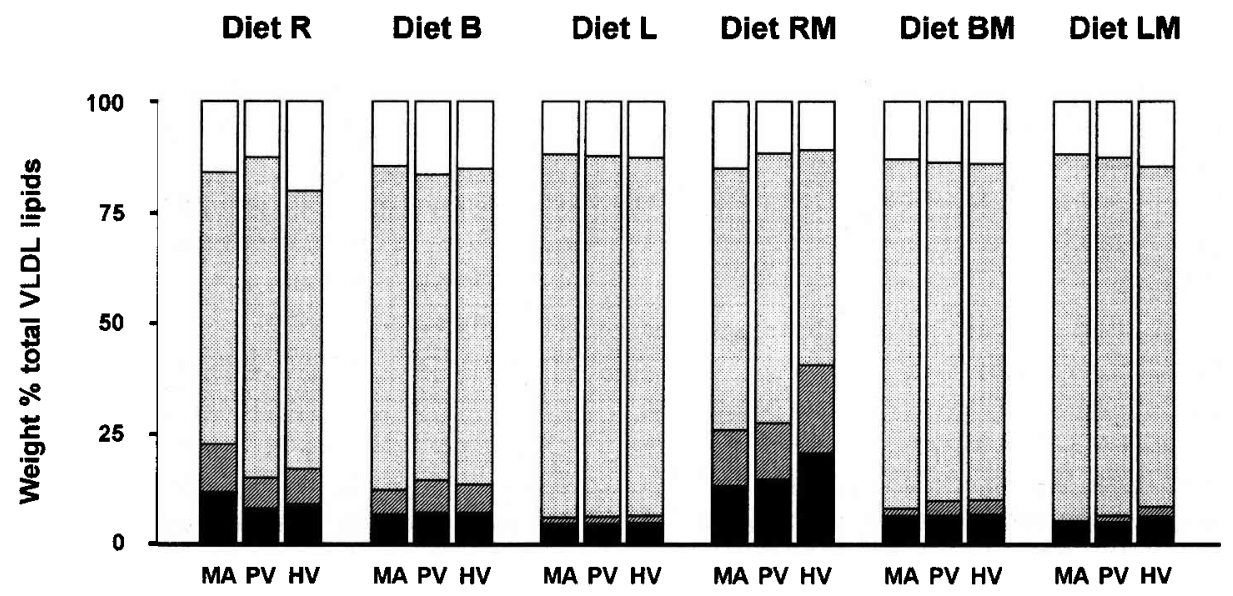

Fig 1. Mean lipid composition (free cholesterol, $\square$; triglycerides, $\square$; cholesteryl esters, $\mathscr{Z}$; phospholipids, $\square$; mean weight percentage of total VLDL lipids) in plasma VLDL from the mesenteric artery (MA), hepatic vein (HV) and portal vein (PV) of preruminant calves fed the lipid-restricted diet (diet $R$, $n=4$ ), basal diet (diet $B, n=4$ ), and lipid-enriched diet (diet $L, n=4$ ), and the same diets with Lmethionine (2.6 $\mathrm{g} / \mathrm{kg}$ of dry matter) (diets RM, BM and $\mathrm{LM}, n=4$ for each diet).

Table II. Mean chemical composition (\% total lipoprotein mass) of VLDL $(d<1.006 \mathrm{~g} / \mathrm{ml})$ in plasma from a mesenteric artery of preruminant calves fed lipid-restricted diet (diet R), basal diet (diet B) and lipid-enriched diet (diet $L$ ) or these diets supplemented with L-methionine ( $2.6 \mathrm{~g} / \mathrm{kg}$ dry matter; diets RM, BM and LM).

\begin{tabular}{|c|c|c|c|c|c|}
\hline \multicolumn{6}{|c|}{ VLDL chemical composition (\%) * } \\
\hline \multicolumn{2}{|c|}{ Lipid-restricted diet } & \multicolumn{2}{|c|}{ Basal diet } & \multicolumn{2}{|c|}{ Lipid-enriched diet } \\
\hline $\begin{array}{l}\text { Control } \\
\text { (diet R) }\end{array}$ & $\begin{array}{c}\text { Methionine } \\
\text { (diet } R M \text { ) }\end{array}$ & $\begin{array}{l}\text { Control } \\
\text { (diet B) }\end{array}$ & $\begin{array}{c}\text { Methionine } \\
\text { (diet } B M \text { ) }\end{array}$ & $\begin{array}{l}\text { Control } \\
\text { (diet L) }\end{array}$ & $\begin{array}{l}\text { Methionine } \\
\text { (diet LM) }\end{array}$ \\
\hline $8.9 \pm 3.1^{a b}$ & $10.7 \pm 2.8^{a}$ & $5.8 \pm 0.3^{b}$ & $5.4 \pm 1.7^{b}$ & $4.0 \pm 0.8^{b}$ & $4.2 \pm 1.4^{b}$ \\
\hline $8.6 \pm 1.7^{\mathrm{a}}$ & $10.3 \pm 4.7^{a}$ & $4.5 \pm 3.5^{\mathrm{ab}}$ & $1.3 \pm 1.1^{b}$ & $1.2 \pm 0.9^{b}$ & $0.8 \pm 0.2^{b}$ \\
\hline $48.3 \pm 8.7^{a}$ & $47.4 \pm 11.9^{a}$ & $60.9 \pm 6.1^{\mathrm{ab}}$ & $65.2 \pm 2.4^{b}$ & $68.7 \pm 1.8^{\mathrm{b}}$ & $67.8 \pm 2.9^{b}$ \\
\hline $13.9 \pm 4.4^{a b}$ & $15.5 \pm 1.7^{\mathrm{a}}$ & $11.9 \pm 1.9 \mathrm{~b}$ & $10.7 \pm 1.1^{\mathrm{b}}$ & $9.8 \pm 1.2^{b}$ & $9.6 \pm 0.9^{b}$ \\
\hline $20.3 \pm 8.2$ & $19.6 \pm 5.5$ & $16.9 \pm 2.0$ & $17.4 \pm 0.7$ & $16.4 \pm 1.2$ & $16.7 \pm 0.6$ \\
\hline
\end{tabular}

\footnotetext{
* Values are the mean \pm SEM of duplicate analyses on plasma from 4 calves in each group. a-b Means values with different superscript letters are significantly different $(P<0.05)$.
} 
plasma VLDL was twice as high when Lmethionine was added to these diets than to the control diets.

Addition of lipids to diets generally led to a stimulation of the in vivo apparent secre- tion of VLDL by the liver (table V), and especially in the case of the lipid-supplemented diet as compared to the lipid-restricted diet $(P<0.10)$. Increase in VLDL apparent secretion was positively correlated with

Table III. Apo B content (mean percentage VLDL weight) and apo B plasma level (mg/dl plasma) of VLDL $(d<1.006 \mathrm{~g} / \mathrm{ml})$ determined by radial immunodiffusion with antibody against bovine apo $B$.

\begin{tabular}{|c|c|c|c|c|c|}
\hline \multicolumn{2}{|c|}{ Lipid restricted diet } & \multicolumn{2}{|c|}{ Basal diet } & \multicolumn{2}{|c|}{ Lipid-enriched diet } \\
\hline $\begin{array}{l}\text { Control } \\
\text { (diet } R \text { ) }\end{array}$ & $\begin{array}{l}\text { Methionine } \\
\text { (diet } R M \text { ) }\end{array}$ & $\begin{array}{l}\text { Control } \\
\text { (diet B) }\end{array}$ & $\begin{array}{l}\text { Methionine } \\
\text { (diet BM) }\end{array}$ & $\begin{array}{l}\text { Control } \\
\text { (diet } L \text { ) }\end{array}$ & $\begin{array}{c}\text { Methionine } \\
\text { (diet } L M \text { ) }\end{array}$ \\
\hline
\end{tabular}

$\begin{array}{lllllll}\text { Apo } B(\% \text { mean } V L D L \text { weight) } & \\ \text { Mesenteric artery } & 2.7 \pm 2.1 & 2.3 \pm 2.7 & 1.2 \pm 0.8 & 1.2 \pm 0.3 & 1.1 \pm 0.5 & 0.8 \pm 0.1 \\ \text { Portal vein } & 2.5 \pm 1.7^{\mathrm{a}} & 3.0 \pm 2.1^{\mathrm{a}} & 1.4 \pm 0.9^{\mathrm{ab}} & 1.1 \pm 0.9^{\mathrm{ab}} & 1.1 \pm 0.4^{\mathrm{b}} & 0.9 \pm 0.2^{\mathrm{b}} \\ \text { Hepatic vein } & 2.6 \pm 2.1 & 1.6 \pm 2.5 & 1.0 \pm 1.2 & 1.5 \pm 0.7 & 1.1 \pm 0.2 & 1.5 \pm 1.0\end{array}$

Apo B ( $m g / d l)$

$\begin{array}{lllllll}\text { Mesenteric artery } & 0.15 \pm 0.12 & 0.05 \pm 0.07 & 0.12 \pm 0.09 & 0.17 \pm 0.03 & 0.17 \pm 0.01 & 0.18 \pm 0.05 \\ \text { Portal vein } & 0.19 \pm 0.07^{\mathrm{c}} & 0.07 \pm 0.05^{\mathrm{d}} & 0.09 \pm 0.07^{\mathrm{d}} & 0.14 \pm 0.09^{\mathrm{cd}} & 0.19 \pm 0.04^{\mathrm{c}} & 0.17 \pm 0.07^{\mathrm{c}} \\ \text { Hepatic vein } & 0.18 \pm 0.14^{\mathrm{b}} & 0.05 \pm 0.06^{\mathrm{a}} & 0.08 \pm 0.09^{\mathrm{ab}} & 0.15 \pm 0.03^{\mathrm{b}} & 0.20 \pm 0.05^{\mathrm{b}} & 0.17 \pm 0.07^{\mathrm{b}}\end{array}$

VLDL were isolated by flotation ultracentrifugation in plasma from the mesenteric artery, hepatic vein and portal vein of preruminant calves fed lipid-restricted diet (diet R), basal diet (diet B) and lipid-enriched diet (diet L) or same diets supplemented with L-methionine $(2.6 \mathrm{~g} / \mathrm{kg}$ dry matter; diets $\mathrm{RM}, \mathrm{BM}$ and $\mathrm{LM}$ ). * Values are the mean $\pm \mathrm{SEM}$ of duplicate analyses on plasma from 4 calves in each group. a-d Mean values with different superscript letters were significantly different: $a, b(P<0.10)$; c,d $(P<0.05)$.

Table IV. Concentration (mg/dl) of VLDL $(d<1.006 \mathrm{~g} / \mathrm{ml})$ isolated by flotation ultracentrifugation in plasma from the mesenteric artery, hepatic vein and portal vein of preruminant calves fed lipid-restricted diet (diet R), basal diet (diet B) and lipid-supplemented diet (diet $L$ ) or the same diets supplemented with $\mathrm{L}-$ methionine $(2.6 \mathrm{~g} / \mathrm{kg}$ dry matter; diets RM, BM and LM).

Plasma concentration of VLDL $(\mathrm{mg} / \mathrm{dl})$ *

\begin{tabular}{cccccc}
\multicolumn{2}{c}{ Lipid-restricted diet } & \multicolumn{2}{c}{ Basal diet } & \multicolumn{2}{c}{ Lipid enriched diet } \\
\hdashline $\begin{array}{cccc}\text { Control } \\
\text { (diet } R \text { ) }\end{array}$ & $\begin{array}{c}\text { Methionine } \\
\text { (diet } R M)\end{array}$ & $\begin{array}{c}\text { Control } \\
\text { (diet } B)\end{array}$ & $\begin{array}{c}\text { Methionine } \\
\text { (diet } B M \text { ) }\end{array}$ & $\begin{array}{c}\text { Control } \\
\text { (diet } L \text { ) }\end{array}$ & $\begin{array}{c}\text { Methionine } \\
\text { (diet } L M \text { ) }\end{array}$
\end{tabular}

$\begin{array}{lrlllll}\text { Mesenteric artery } & 5.3 \pm 4.1^{\mathrm{a}} & 2.0 \pm 1.0^{\mathrm{a}} & 8.4 \pm 4.1^{\mathrm{b}} & 14.7 \pm 3.6^{\mathrm{bc}} & 17.4 \pm 5.7^{\mathrm{c}} & 23.3 \pm 2.7^{\mathrm{c}} \\ \text { Portal vein } & 10.2 \pm 6.4^{\mathrm{b}} & 2.0 \pm 1.3^{\mathrm{a}} & 5.5 \pm 3.0^{\mathrm{a}} & 11.2 \pm 5.8^{\mathrm{ab}} & 17.1 \pm 3.1^{\mathrm{b}} & 19.0 \pm 8.9^{\mathrm{b}} \\ \text { Hepatic vein } & 6.0 \pm 4.4^{\mathrm{a}} & 2.5 \pm 2.1^{\mathrm{a}} & 4.9 \pm 3.3^{\mathrm{a}} & 12.3 \pm 5.8^{\mathrm{ab}} & 18.9 \pm 5.4^{\mathrm{b}} & 14.7 \pm 8.5^{\mathrm{b}}\end{array}$

\footnotetext{
* Values are the mean \pm SEM of duplicate analyses on plasma from 4 calves in each group. a-c Mean values with different superscript letters were significantly different $(P<0.05)$.
} 


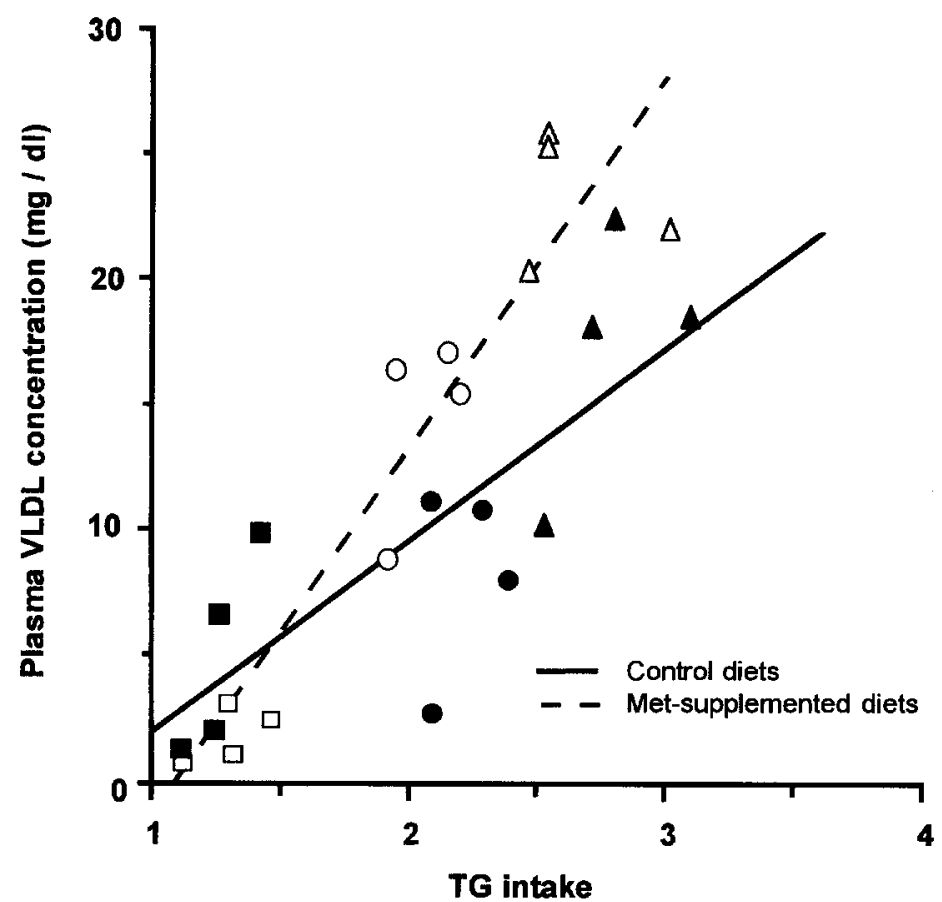

( $\mathrm{g} / \mathrm{kg}$ of body weight per meal)
Fig 2. Individual plasma concentrations $(\mathrm{mg} / \mathrm{dl})$ of VLDL $(d<1.006$ $\mathrm{g} / \mathrm{ml}$ ) isolated by flotation ultracentrifugation from the mesenteric artery of preruminant calves fed the lipidrestricted diet (diet $R$, 口), basal diet (diet B, ), lipidenriched diet (diet L, $\Delta)$ and the same diets (diet RM, $\square$; diet BM, O; diet LM, $\Delta$ ) with L-methionine $(2.6 \mathrm{~g} / \mathrm{kg}$ of dry matter). increase in the hepatic apparent secretion of VLDL apo B $(0.009 \pm 0.030$ versus $0.005 \pm$ $0.011 \mathrm{mg} / \mathrm{min}$ per $\mathrm{kg}$ of $B W$ for diets $L$ and $R$, respectively). Addition of L-methionine to diets $R$ and $B$ enhanced the net apparent secretion of VLDL by the liver because the negative hepatic balance observed for the control diets became positive in the presence of L-methionine (table V). On the other hand, the negative and significant $(P<0.10)$ effects of L-methionine on the hepatic apparent secretion of VLDL was noted with the lipid-supplemented diet (diet LM).

\section{DISCUSSION}

In dairy cattle, VLDL secretion by the liver is considered to be low when compared to triglyceride synthesis (Herdt et al, 1988), which would explain the moderate to severe hepatic lipidosis noted in one-third of periparturient, high-producing cows (Reid and Roberts, 1983). In humans, VLDL production by the liver and the role of various factors in its regulation have been extensively studied in view of the identification of increase of plasma triglyceride levels as a major risk factor in heart disease (Castelli, 1986). Studies on hepatocytes in culture or on perfused liver in humans and rodents have indicated that cellular VLDL synthesis may be regulated at several levels, including the biosynthesis of the various lipid and protein constituents of these particles and the assembly and subsequent maturation of nascent VLDL (Yao and Vance, 1988; Gibbons, 1990; Vance, 1990). The level of fat intake appeared to be an important factor controlling the rate of VLDL secretion by both the liver and the intes- 
Table V. Hepatic balance $(\mathrm{mg} / \mathrm{min} / \mathrm{kg} \mathrm{BW})$ of plasma VLDL $(d<1.006 \mathrm{~g} / \mathrm{ml})$ isolated by flotation ultracentrifugation in plasma from the mesenteric artery, hepatic vein and portal vein of preruminant calves fed lipid-restricted diet (diet R), basal diet (diet B) and lipid-supplemented diet (diet $L$ ) or the same diets supplemented with L-methionine ( $2.6 \mathrm{~g} / \mathrm{kg}$ dry matter; diets RM, BM and LM).

Diet

Hepatic balance of VLDL $(\mathrm{mg} / \mathrm{min} / \mathrm{kg} \mathrm{BW})^{*}$

\begin{tabular}{|c|c|}
\hline Diet $R$ & \\
\hline Control & $-1.51 \pm 1.77^{a}$ \\
\hline Methionine & $0.25 \pm 0.86^{\mathrm{ab}}$ \\
\hline Diet B & \\
\hline Control & $-0.36 \pm 0.94 a b$ \\
\hline Methionine & $0.35 \pm 2.78^{a b}$ \\
\hline Diet $L$ & \\
\hline Control & $1.02 \pm 2.13^{b}$ \\
\hline Methionine & $-2.16 \pm 0.22^{a}$ \\
\hline $\begin{array}{l}\text { Hepatic balance } \\
C_{\mathrm{PV}} F_{\mathrm{PV}}+C_{\mathrm{HA}} F \\
\text { methods). }{ }^{*} \text { Value } \\
\text { analyses on plas } \\
\text { Mean values with } \\
\text { ficantly different ( }\end{array}$ & $\begin{array}{l}\text { ssed as: }\left(C_{\mathrm{HV}}\left(F_{\mathrm{PV}}+F_{\mathrm{HA}}\right)-\right. \\
\text { details, see Materials and } \\
\text { e means } \pm \text { SEM of duplicate } \\
4 \text { calves in each group. a-b } \\
\text { superscript letters were signi- } \\
\text { ). }\end{array}$ \\
\hline
\end{tabular}

tine. Under fasting conditions, secretion of VLDL by cultured hepatocytes in the rat (Gibbons and Burnham, 1991) and by the intact liver in the preruminant calf (Bauchart et al, 1989) was shown to be strongly depressed. Under such dietary conditions, the low secretion of VLDL in the rat concerned all lipid classes of these particles as well as apo B48 (Davis et al, 1985), whereas apo B100 secretion remained unchanged (Leighton et al, 1990).

The negative hepatic balance for VLDL determined under fasting conditions in the preruminant calf (Bauchart et al, 1989), in the dairy cow (Reid et al, 1979a), or with lipid-restricted or basal diets (diets $R$ and $B$ ) in the preruminant calf in our experiment, indicated that rates of VLDL uptake exceeded VLDL secretion rates by the liver in vivo. However, the occurrence of a positive hepatic balance for VLDL in our calves which received a high fat diet (diet $L$ ) has been observed previously in cows (Reid et al, 1979a). Although the differences between lipid-restricted and lipid-enriched diets were significant only at $P<0.10$, these results suggest a stimulation of VLDL synthesis by circulating dietary fatty acids administered as TG, in addition to a possible decrease of VLDL uptake. Similar observations have been reported for the intense uptake of circulating NEFA during the development of a fatty liver in the dairy cow (Herdt et al, 1983; Pullen et al, 1989).

Variations in the rate of VLDL secretion with the level of fat intake were associated with modification in the chemical composition of VLDL particles. The accumulation of cholesterol (mainly as CE) in the VLDL particles in TG-restricted diets confirmed the notion that de novo synthesis of longchain fatty acids and their conversion into VLDL-TG occurs at a low rate in the liver of bovine species and is insufficient to compensate for the low supply of dietary fatty acids by these diets in our experiment.

A decrease in the apo B content (expressed as percentage weight of total VLDL particles) of VLDL particles coupled with an increase in fat intake has been described previously in rat hepatocytes (Patsch et al, 1983). It was explained on the basis of an increase in particle size resulting from preferential incorporation of triglycerides (Vance and Vance, 1990) and by the fact that, as in rat and humans, only one molecule of apo $B$ is present in each VLDL particle (Elovson et al, 1988). However, possible regulation of apo $B$ synthesis by dietary fatty acids should not be excluded, although it remains a much debated question (Vance and Vance, 1990). In the perfused rat liver, oleic acid did not 
stimulate secretion of apo B (Salam et al, 1988), whereas it had a positive effect in HepG2 cell cultures (Moberly et al, 1990; Arrol et al, 1991; Dixon and Ginsberg, 1993). Hepatic TG are mainly implicated in the modulation of apo B secretion by oleate. Indeed, in the HepG2 cells, apo B secretion was stimulated by oleate with a short lag phase (40 min) and, conversely, this apo $B$ secretion returned to the control rate with a similar lag phase when oleate was removed from the medium (Dixon and Ginsberg, 1993). However, treatment of primary cultures of hamster hepatocytes with oleate stimulated TG synthesis without modifying apo $B$ secretion but the decrease in TG synthesis reduced the apo B secretion (Arbeeny et al, 1992).

Irrespective of the influence of dietary fatty acids on apo B secretion, it is clear that VLDL particles are not secreted without the presence of apo B (Vance and Vance, 1990). It is therefore probable that apo $B$ production is one of the main factors limiting VLDL secretion in bovine species. It was demonstrated in goat hepatocytes that longchain fatty acids were esterified with the same efficiency as in rat hepatocytes, but the rate of VLDL secretion was 20-25 times lower (Kleppe et al, 1988; Armentano et al, 1991). From studies in HepG2 cells (Pullinger et al, 1989), nutritional and hormonal regulations of hepatic apo $B$ secretion did not seem to be modulated at transcription but rather at the translation or posttranslation levels.

Enhancement by L-methionine of apparent VLDL secretion by the liver with diets $R$ and $B$ was not significant mainly because of a large between-animal variability. However, stimulating effects of L-methionine were observed for most of the animals in both groups. It seemed to indicate that this sulfur-containing amino acid is a limiting factor in hepatic TG secretion in bovine species, as has been proposed by Moore and Christie (1981). It is unclear whether this amino acid acts in the calf as a precursor for both lecithin and apo B synthesis (Moore and Christie, 1981). Similar stimulation of apparent VLDL secretion by the liver was observed in the early lactation in the dairy cow when infused with a mixture of L-methionine and L-lysine into the mesenteric vein (Durand et al, 1992). The lack of effect of L-methionine in association with our lipid-enriched diet (diet LM) was unexpected. This might result from an insufficient dose of L-methionine as compared to the high level of fat intake or from a possible competition between liver and intestine for $L$ methionine uptake. Indeed, recent studies of chylomicron metabolism in methionine-supplemented diet in the preruminant calf (Auboiron et al, 1994) show that L-methionine leads to a marked increase in plasma levels of chylomicrons in peripheral blood, indicating possible stimulation of the secretion of this TG-rich lipoprotein by the intestine.

\section{ACKNOWLEDGMENTS}

The authors are grateful to $J$ Lefaivre for the animal surgery, to M Martinaud and C Legay for their skillful technical assistance and to $\mathrm{R}$ Souchet and $C$ Léoty for the excellent maintenance and care of the animals.

\section{REFERENCES}

Arbeeny CM, Meyers DS, Bergquist KE, Gregg RE (1992) Inhibition of fatty acid synthesis decreases very low density lipoprotein secretion in the hamster. J Lipid Res 33, 843-851

Armentano LE, Grummer RR, Bertics SJ, Skaar TC, Donkin SS (1991) Effect of energy balance on hepatic capacity for oleate and propionate metabolism and triglyceride secretion. J Dairy Sci 74, 132-139

Arrol S, Mackness MI, Laing I, Durrington PN (1991) Lipoprotein secretion by the human hepatoma cell line HepG2: differential rates of accumulation of apolipoprotein B and lipoprotein lipids in tissue culture media in response to albumin, glucose and oleate. Biochem Biophys Acta 1086, 72-80 
Auboiron S, Durand D, Laplaud PM, Levieux D, Bauchart D. Chapman MJ (1990) Determination of the respective density distributions of low and high density lipoprotein particles in bovine plasma and lymph by immunoassay of apoproteins A-l and B. Reprod Nutr Dev 2, 227s (abstr)

Auboiron S, Durand D, Lefaivre J, Bauchard D, Chapman MJ (1992) Estrogen-induced changes in the hepatic metabolism of plasma lipoproteins in the preruminant calf. Ann Zootech 41, 117 (abstr)

Auboiron S, Durand D, Robert JC, Chapman MJ, Bauchart D (1994) Lipoprotein metabolism in the preruminant calf, Bos spp; effect of a high fat diet supplemented with L-methionine. J Dairy Sci 77, 1870-1881

Bauchart D (1993) Lipid absorption and transport in ruminant animals. J Dairy Sci 76, 3864-3881

Bauchart D, Durand D, Laplaud PM, Forgez P, Goulinet S, Chapman MJ (1989) Plasma lipoproteins and apolipoproteins in the preruminant calf, Bos spp: density distribution, physicochemical properties, and the in vivo evaluation of the contribution of the liver to lipoprotein homeostasis. J Lipid Res 30, 1499-1513

Castelli WP (1986) The triglyceride issue: a review for Framingham. Am Heart $J 112,432-437$

Chow IM, DePeters EJ, Baldwin RL (1990) Effect of rumen-protected methionine and lysine on casein milk when diets high in fat or concentrate are fed. J Dairy Sci 73, 1051-1061

Davis RA, Boogaerts JR, Borchardt RA, Malone-McNeal M, Archambault-Schexnayder J (1985) Intrahepatic assembly of very low density lipoproteins: varied synthetic response of individual apolipoproteins to fasting. J Biol Chem 260, 14137-14144

Dixon JL, Ginsberg HN (1993) Regulation of hepatic secretion of apolipoprotein B-containing lipoproteins: information obtained from cultured liver cells. $J$ Lipid Res 34, 167-179

Durand D, Bauchart D, Lefaivre J, Donnat JP (1988) Method for continuous measurement of blood metabolite hepatic balance in conscious preruminant calves using catheters and electromagnetic flowmetry. J Dairy Sci 71, 1632-1642

Durand D, Chilliard Y, Bauchart D (1992) Effects of lysine and methionine on in vivo hepatic secretion of VLDL in the high-yielding dairy cow. J Dairy Sci 75 (suppl 1), 279 (abstr)

Elovson J, Chatterton JE, Bell GT et al (1988) Plasma very low density lipoproteins contain a single molecule of apolipoprotein B. J Lipid Res 29, 1461-1473

Emmanuel B, Kennelly JJ (1984) Kinetics of methionine and choline and their incorporation into plasma lipids and milk components in lactating goats. $J$ Dairy Sci67, 1912-1918

Gibbons GF (1990) Assembly and secretion of hepatic very low density lipoproteins. Biochem J 268, 1-13
Gibbons GF, Burnham FJ (1991) Effect of nutritional state on the utilization of fatty acids for hepatic triacylglycerol synthesis and secretion as very low density lipoprotein. Biochem J 275, 87-92

Grummer RR (1993) Dietary fat effects on mammary metabolism and milk composition. J Dairy Sci 76, 3882-3896

Grummer RR, Bertics SJ, Snow JA, Lacount DW (1989) Effects of estrogen $(E)$ administration to late lactation, nonpregnant dairy cows on hepatic lipid content and plasma triglyceride-rich lipoprotein (TGLP) concentration. J Anim Sci67, 396 (abstr)

Herdt TH, Liesman JS, Gerloff BJ, Emery RS (1983) Reduction of serum triacylglycerol-rich lipoprotein concentrations in cows with hepatic lipidosis. $A m J$ Vet Res 44, 293-296

Herdt TH, Wensing T, Haagsman HP, VanGolde LMG, Breukink HJ (1988) Hepatic triacylglycerol synthesis during a period of fatty liver development in sheep. J Dairy Sci 66, 1997-2013

Kleppe BB, Aiello RJ, Grummer RR, Armentano LE (1988) Triglyceride accumulation and very low density lipoprotein secretion by rat and goat hepatocytes in vitro. J Dairy Sci 71, 1813-1822

Leighton JK, Joyner J, Zamarripa J, Deines M, Davis RA (1990) Fasting decreases apolipoprotein B mRNA editing and the secretion of small molecular weight apo $B$ by rat hepatocytes: evidence that the total amount of apo B secreted is regulated posttranscriptionally. J Lipid Res 31, 1663-1668

Leplaix L, Bauchart D, Durand D, Laplaud PM, Chapman MJ (1992) Effects of dietary cholesterol on hepatic metabolism of triglyceride-rich lipoproteins in the preruminant calf, Bos spp. Reprod Nutr Dev 32 , 490 (abstr)

Mancini G, Carbonara AO, Heremans JF (1965) Immunochemical quantitation of antigens by single radial immunodiffusion. Immunochemistry 2,235 254

Mann HB, Whitney DR (1947) On the test whether one of two random variables is stochastically larger than the other. Ann Math Stat 1, 50-60

Moberly JB, Cole TG, Alpers DH, Schonfeld G (1990) Oleic stimulation of apolipoproteins $B$ secretion from HepG2 and Caco-2 cells occurs post-transcriptionally. Biochim Biophys Acta 1042, 70-80

Moore JH, Christie WW (1981) Lipid metabolism in the mammary giand of ruminant animals. In: Lipid Metabolism in Ruminant Animals (WW Christie , ed), Pergamon Press, Oxford, UK, 227-245

Patsch W, Tamai T, Schonfeld G (1983) Effect of fatty acids on lipid and apolipoprotein secretion and association in hepatocyte cultures. J Clin Invest 721, 371378

Patterson JA, Kung $L$ (1988) Metabolism of DL-methionine and methionine analogs by rumen microorganisms. J Dairy Sci 71, 3292-3301 
Pullen DL, Emery RS, Ames NK (1988) Turnover of hepatic and plasma triacylglycerol in sheep. J Anim Sci $66,1538-1547$

Pullen DL, Palmquist DL, Emery RS (1989) Effect on days of lactation and methionine hydroxy analog on incorporation of plasma fatty acids into plasma triglycerides. J Dairy Sci $72,49-58$

Pullinger CR, North JD, Teng BB, Rifici VA, Ronhild de Brito $A E$, Scott J (1989) The apolipoprotein gene is constitutively expressed in HepG2 cells: regulation of secretion by oleic acid, albumin, and insulin, and measurement of the mRNA-half life. J Lipid Res 30 , 1065-1077

Reid IM, Roberts CJ (1983) Subclinical fatty liver in dairy cows. Current research and future prospects. Ir Vet $J 37,104-110$

Reid IM, Collins RA, Baird GD, Roberts CJ, Sydmonds HW (1979a) Lipid production rates and the pathogenesis of fatty liver in fasted cows. J Agric Sci Camb 93, 253-256

Reid IM, Roberts CJ, Manston R (1979b) Fatty liver and infertility in high-yielding dairy cows. Vet Rec 104, 75-76

Reid IM, Dew SM, Collins RA, Ducker MJ, Bloomfield GA, Morant SV (1983) The relationship between fatty liver and fertility in dairy cows: a farm investigation. J Agric Sci Camb 101, 499-502

Salam WH, Wilcox HG, Heimberg M (1988) Effects of oleic acid on biosynthesis of lipoprotein apoproteins and distribution into the very low density lipoprotein by the isolated perfused rat liver. Biochem J 251, 809-816
Snedecor GW, Cochran WG (1967) Statistical Methods. The lowa State University Press, Ames, IA USA, 172-195

Sorci-Thomas M, Wilson MD, Johnson FL, Williams DL, Rudel LL (1989) Studies on the expression of genes encoding apolipoprotein B100 and B48 and the low density lipoprotein receptor in non-human primates. $J$ Biol Chem 264, 9039-9045

Toullec R (1978) Le Veau. In: INRA, Alimentation des Ruminants (INRA Publications, ed), Versailles, France, 270-271

Vance DE (1990) Phosphatidylcholine metabolism: masochistic enzymology, metabolic regulation, and lipoprotein assembly. Biochem Cell Biol 68, 11511165

Vance JE, Vance DE (1990) The assembly of lipids into lipoproteins during secretion. Experentia 46, 560569

Yao Z, Vance DE (1988) The active synthesis of phosphatidylcholine is required for very low density lipoprotein secretion from rat hepatocytes. J Biol Chem 263, 2998-3004

Zammit VA (1990) Ketogenesis in the liver of ruminants; adaptations to a challenge. A review. J Agric Sci Camb 115, 155-162

Zilversmit DB (1969) Chylomicrons. In: Structural and Functional Aspects of Lipoproteins in Living Systems (E Tria, AM Scanu, eds), Academic Press, London, UK, 329-368 